\title{
Severe hypophosphatemia in the critically ill: are we replacing enough?
}

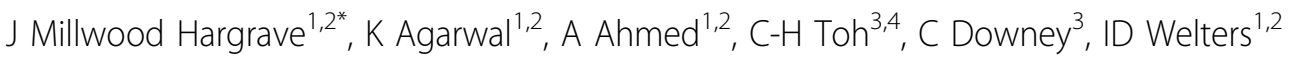 \\ From ESICM LIVES 2015 \\ Berlin, Germany. 3-7 October 2015
}

\section{Introduction}

Severe hypophosphatemia is frequently seen in the critically ill, and its presence is associated with significant morbidity. Although phosphate correction is commonly performed in a critical care environment, the optimal amount of phosphate supplementation and the role of serum phosphate levels in the early days following admission remains uncertain.

\section{Objectives}

We sought to establish the course of severe hypophosphatemia in the early days of critical illness (Day 1 - 7) and to ascertain whether phosphate supplementation delivered to severely hypophosphatemic patients led to appropriate rise in serum phosphate concentrations.

\section{Methods}

Patient data over seven days following admission was retrospectively collected for 1,038 admissions to critical care units of a tertiary hospital. 22 patients with severe hypophosphatemia (Serum phosphate $<0.4 \mathrm{mmol} / \mathrm{l}$ ) were identified from this data set. In these patients, demographic and clinical data as well as time course of serum phosphate concentrations and total oral and parenteral phosphate supplementation were recorded. The clinical course for serum phosphate levels was observed during the first seven days following admission. A local protocol for phosphate replacement is in place which suggests administration of up to $40 \mathrm{mmol} /$ day in severe hypophosphatemia. All patients received phosphate supplementation within the seven days following admission, and the daily supplementation given was compared to the recommended phosphate supplementation as per local protocol.

${ }^{1}$ Royal Liverpool University Hospital, Intensive Care Unit, Liverpool, United Kingdom

Full list of author information is available at the end of the article

\section{Results}

22 patients were eligible for inclusion. The mean age was $48.2 \pm 15.5$ years, the mean APACHE II score $18.9 \pm 7.0$, and $50 \%$ of patients were female. Mean serum phosphate levels normalised from admission $(0.32 \mathrm{mmol} / \mathrm{l} \pm 0.06)$ to day five $(0.90 \mathrm{mmol} / \mathrm{l} \pm 0.22)$ in the majority of patients (73.7\%).

There was a significant difference between the phosphate supplementation severely hypophosphatemic patients received $(7.23 \pm 4.85 \mathrm{mmol})$ compared to the recommended phosphate replacement $(14.91 \mathrm{mmol})$ as per local protocol, over the first seven days following admission.

\section{Conclusions}

Phosphate supplementation in severe hypophosphatemia is less than recommended. As a consequence, normalisation of phosphate levels was achieved only after 5 days of Intensive Care and only in about three quarter of severely hypophosphatemic patients. This may reflect the need for more aggressive phosphate supplementation in our critical care unit.

\section{Grant Acknowledgment}

We have read and understood ESICM policy on declaration of grants and declare that we have received no grants for this project.

\section{Authors' details}

${ }^{1}$ Royal Liverpool University Hospital, Intensive Care Unit, Liverpool, United Kingdom. ${ }^{2}$ University of Liverpool, Institute of Ageing and Chronic Disease, Liverpool, United Kingdom. ${ }^{3}$ Royal Liverpool University Hospital, Department of Haematology, Liverpool, United Kingdom. ${ }^{4}$ University of Liverpool, Institute of Infection and Global Health, Liverpool, United Kingdom.

Published: 1 October 2015

\section{SpringerOpen ${ }^{\circ}$}

(c) 2015 Millwood Hargrave et al.; This is an Open Access article distributed under the terms of the Creative Commons Attribution License (http://creativecommons.org/licenses/by/4.0), which permits unrestricted use, distribution, and reproduction in any medium, provided the original work is properly cited. 


\section{References}

1. Amanzadeh J, Reilly RF Jr: Hypophosphatemia: an evidence-based approach to its clinical consequences and management. Nature clinical practice Nephrology 2006, 2:136-48.

2. Geerse DA, Bindels AJ, et al: Treatment of hypophosphatemia in the intensive care unit: a review. Critical Care 2010, 14:R147.

doi:10.1186/2197-425X-3-S1-A913

Cite this article as: Millwood Hargrave et al:: Severe hypophosphatemia

in the critically ill: are we replacing enough? Intensive Care Medicine

Experimental 2015 3(Suppl 1):A913.

\section{Submit your manuscript to a SpringerOpen ${ }^{\mathcal{D}}$} journal and benefit from:

- Convenient online submission

- Rigorous peer review

- Immediate publication on acceptance

- Open access: articles freely available online

- High visibility within the field

- Retaining the copyright to your article

Submit your next manuscript at $\gg$ springeropen.com 